\begin{tabular}{|c|c|c|}
\hline$\xi$ & $\begin{array}{c}\text { International Journal of Current Research } \\
\text { and Academic Review }\end{array}$ & 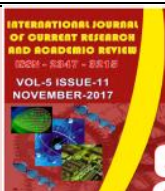 \\
\hline $\begin{array}{l}\text { EXCELLENT } \\
\text { PUBLISHERS } \\
\end{array}$ & Journal homepage: http://www.ijcrar.com & \\
\hline
\end{tabular}

doi: https://doi.org/10.20546/ijcrar.2017.511.008

\title{
Bioremediation of Industrial Effluents Using Fresh Water Cyanobacterial Species
}

\author{
S. Sagunthala and R. Sivakami* \\ Department of Zoology, Arignar Anna Govt. Arts College, Musiri-621211, Tamil Nadu, India \\ *Corresponding author
}

\begin{abstract}
Today cyanobacteria are widely used in bioremediation of industrial effluents. Hence the present study was attempted to analyse the effect of individual and combination effect of Cyanobacterial species isolated from Mukkumbu, the River Cauvery on bioremediation of pollutants. Results indicate that all the species showed the ability to degrade pollutants. However, the growth and degradable abilities were found to differ in different species, pollutant concentration and exposure; while the Cyanobacterial combination performed better at low concentrations, individual organisms recorded higher degradability at higher concentration. Thus, the results clearly demonstrate the ability of the organisms to degrade the pollutants. However, the growth and degradable abilities were found to differ among the species, pollutant concentration as well as the exposure time.
\end{abstract}

\section{Article Info}

Accepted: 28 October 2017

Available Online:20 November 2017

\section{Keywords}

Bioremediation,

Fresh water,

Cyanobacteria/algae,

Cyanobacterial combination,

Different concentration

\section{Introduction}

Cyanobacteria are known to occupy a vast variety of habitats even though they are susceptible to sudden physical and chemical changes in light, salinity, temperature and nutrient availability (Boominathan, 2005; Semyalo, 2009).

Today, they are widely used in waste water and industrial effluent treatment, bioremediation of aquatic and terrestrial habitats, chemical industries, biofertilizers, food, feed, etc. (Cairns and Dickson, 1971) besides being a source of fine chemicals and as a source of renewable fuel (Lem and Glck, 1985).

With increasing pollution, there has been a series of studies to combat it and one of the thrust areas has been the use of bioremediation measures using cyanobacteria. However, the beneficial application of cyanobacteria in remediation of contaminated waters either in natural aquatic environments or industrial effluents is still not optimally manipulated (Dubey et al., 2011). Hence the present study was done to assess the biodegradable abilities of some naturally occurring cyanobacteria.

\section{Materials and Methods}

\section{Microorganisms}

Cyanobacterial species were isolated from the Cauvery River, Mukkombu of Tiruchirappalli District, Tamil Nadu, India. Micro flora dominates the Cauvery River and small ponds. All species involved in the study were isolated and identified in the Laboratory of Zoology, Arignar Anna Government Arts College, Musiri-621211, Tamil Nadu, India. These species included Anabaena circinalis, Oscillatoria salina, Synechococcus elongatus, Spirulina major and Lyngbya trunicicola. 


\section{Sampling of industrial effluent}

Samples were collected from the paper industry and textile industry effluents, Karur District, Tamil Nadu, India. Grab samples representing all wastes entering the plant during $24 \mathrm{hr}$ were collected from both industries to avoid the fluctuation in the flow and the strength of the influent. Physico-chemical analysis were done according to APHA (1998).

\section{Media and culture conditions}

BG-11 modified medium (SP) was used. This consisted of solutions $\mathrm{A}$ and $\mathrm{B}$, containing (in grams): $\mathrm{A} ; \mathrm{NaHCO}_{3}$ $11.61 \mathrm{~g}, \mathrm{Na}_{2} \mathrm{CO}_{3} 3.53 \mathrm{~g}, \mathrm{~K}_{2} \mathrm{HPO}_{4} 0.5 \mathrm{~g}$ dissolved in 500 $\mathrm{ml}$ distilled water and $\mathrm{B} ; \mathrm{NaNO}_{3} 5 \mathrm{~g}, \mathrm{~K}_{2} \mathrm{SO}_{4} 1 \mathrm{~g}, \mathrm{NaCl} 1$ $\mathrm{g}, \mathrm{MgSO}_{4} .7 \mathrm{H}_{2} \mathrm{O} 0.2 \mathrm{~g}, \mathrm{CaCl}_{2} 0.04 \mathrm{~g}$, and $1 \mathrm{ml}$ EDTA $(0.5 \mathrm{M})$. Micronutrient solution (CHU No.10) consisted of the following trace metals (in milligrams) dissolved in one litre distilled water: $\mathrm{Na}_{2}$-EDTA $50 \mathrm{~g}, \mathrm{H}_{3} \mathrm{BO}_{3} 618 \mathrm{~g}$, $\mathrm{CuSO}_{4} .5 \mathrm{H}_{2} \mathrm{O} 19.6 \mathrm{~g}, \mathrm{ZnSO}_{4} .7 \mathrm{H}_{2} \mathrm{O} 44 \mathrm{~g}, \mathrm{CaCl}_{2} .6 \mathrm{H}_{2} \mathrm{O} 20$ $\mathrm{g}, \mathrm{MnCl}_{2} 12 \mathrm{~g}$ and $\mathrm{Na}_{2} \mathrm{MoO}_{4} \cdot 2 \mathrm{H}_{2} \mathrm{O} 12.6 \mathrm{~g}$. Solutions-A and $\mathrm{B}$ were sterilized by autoclaving separately at $121^{\circ} \mathrm{C}$ for $20 \mathrm{~min}$. Micronutrient solution was sterilized by filtration through $0.22 \mathrm{~mm}$ polycarbonate membrane to avoid interaction and precipitation of heavy metals. After sterilization, solutions-A and B were combined and $1 \mathrm{ml}$ of the micronutrient solution and $1 \mathrm{ml}$ of vitamin $\mathrm{B}_{12}$ (stock solution $15.0 \times 10^{-6} \mathrm{~g}$ ) were added. Two modifications of $\mathrm{BG}_{11}$ were developed in order to define the optimal conditions required for the enrichment and propagation of cyanobacterial isolates and to enhance the natural biodegradation activity of the purified isolates. The first modification was doubling vitamin $B_{12}$ concentration, which enhanced growth. The second was increasing nitrogen content, based on the fact that the enzyme responsible for dechlorination activities (nitrate reductase) is induced at high nitrogen levels (Kuritzet al., 1997). Optimization of cyanobacterial growth included adjusting the light/dark cycle, with $16 / 8 \mathrm{hr}$ of white light $8 \mathrm{ft} 40 \mathrm{~W}$ with light intensity (3200 lux), temperature at 25 to $30^{\circ} \mathrm{C}$, and shaking $(120 \mathrm{rpm})$ of the cultures, all of which led to enhancement of mass production. Prior to biodegradation bioassays, all cultures were tested for the presence of heterotrophic bacteria microscopically and by plating on bacterial nutrient medium (nutrient agar, Difco, UK) and incubating at $30^{\circ} \mathrm{C}$ for 1 week. Only axenic cultures, either uni- or multi-algal species, were used in the assays (Dubey et al., 2011).

\section{Results and Discussion}

The various physico-chemical variables that were analysed during the period of study are presented in Table-1. The degradation efficiency of the individual organisms to various concentrations for a period of nine days are presented in Table-2. At $5 \mathrm{ppm}$ concentration and an exposure period of three days, among the various species analysed, Spirulina major recorded maximum degradation (98.2\%), while after six days, Lyngbya trunicicde (98.6\%) and Anabaena circinalis (98.4\%) recorded maximum degradation and after 9 days, $A$. circinalis recorded maximum degradation (96.4\%); with regard to a residual concentration of $10 \mathrm{ppm}$, results clearly suggest that $L$. trunicicde recorded maximum degrading ability at all the days examined when compared to others. Nevertheless, a closer perusal reveals that the degrading ability of all the organisms showed an increasing trend when compared to a residual concentration of $5 \mathrm{ppm}$. Thus, the results clearly demonstrate the ability of the organisms to degrade the pollutants. However, the growth and degradable abilities were found to differ among the species, pollutant concentration as well as the exposure time.

Table.1 Biodegradation of industrial effluents by the selected cyanobacterial species isolated from Mukkombu, the River Cauvery

\begin{tabular}{|c|c|c|c|c|c|c|}
\hline \multirow{2}{*}{$\begin{array}{l}\text { S. } \\
\text { No. }\end{array}$} & \multirow{2}{*}{ Cyanobacterial species } & \multirow{2}{*}{$\begin{array}{l}\text { Exposure time } \\
\text { (days) }\end{array}$} & \multicolumn{2}{|c|}{$5 \mathrm{ppm}$} & \multicolumn{2}{|c|}{$10 \mathrm{ppm}$} \\
\hline & & & Residual concentration* & Removal efficiency (\%) & Residual concentration* & Removal efficiency $(\%)$ \\
\hline \multirow{3}{*}{1.} & \multirow{3}{*}{$\begin{array}{l}\text { Anabaena circinalis }+ \text { Spirulina } \\
\text { major }\end{array}$} & 3 & 0.03 & 99.5 & 0.40 & 96.0 \\
\hline & & 6 & 0.00 & 100.0 & 0.20 & 99.8 \\
\hline & & 9 & 0.00 & 100.0 & 0.28 & 97.1 \\
\hline \multirow{3}{*}{2.} & \multirow{3}{*}{$\begin{array}{l}\text { Oscillatoria salina } \\
\text { + Spirulina major }\end{array}$} & 3 & 0.16 & 97.2 & 0.39 & 97.0 \\
\hline & & 6 & 0.03 & 99.4 & 0.43 & 95.6 \\
\hline & & 9 & 0.31 & 92.0 & 0.86 & 90.5 \\
\hline \multirow{3}{*}{3.} & \multirow{3}{*}{$\begin{array}{l}\text { Synechococcus elongatus } \\
+ \text { Spirulina major }\end{array}$} & 3 & 0.08 & 99.7 & 0.67 & 99.4 \\
\hline & & 6 & 0.03 & 99.8 & 0.00 & 100.0 \\
\hline & & 9 & 0.05 & 99.0 & 0.84 & 92.0 \\
\hline
\end{tabular}

* Recovery 90\%, Mean standard error 
Table.2 Selected species of Fresh water Cyanobacteria and its removal efficiency

\begin{tabular}{|c|c|c|c|c|c|c|}
\hline \multirow[b]{2}{*}{ S. No. } & \multirow[b]{2}{*}{$\begin{array}{c}\text { Cyanobacterial } \\
\text { species }\end{array}$} & \multirow[b]{2}{*}{$\begin{array}{c}\text { Exposure } \\
\text { time } \\
\text { (days) }\end{array}$} & \multicolumn{2}{|c|}{5 ppm } & \multicolumn{2}{|c|}{10 ppm } \\
\hline & & & $\begin{array}{c}\text { Residual } \\
\text { concentration* }\end{array}$ & $\begin{array}{c}\text { Removal } \\
\text { efficiency } \\
(\%)\end{array}$ & $\begin{array}{c}\text { Residual } \\
\text { concentration* }\end{array}$ & $\begin{array}{c}\text { Removal } \\
\text { efficiency } \\
(\%)\end{array}$ \\
\hline \multirow{3}{*}{1.} & \multirow{3}{*}{ Anabaena circinalis } & 3 & 0.28 & 94.2 & 0.12 & 99.0 \\
\hline & & 6 & 0.81 & 98.4 & 0.18 & 98.2 \\
\hline & & 9 & 0.12 & 96.4 & 1.20 & 90.2 \\
\hline \multirow{3}{*}{2.} & \multirow{3}{*}{ Oscillatoria salina } & 3 & 0.12 & 96.0 & 0.50 & 95.4 \\
\hline & & 6 & 0.18 & 97.0 & 0.19 & 98.4 \\
\hline & & 9 & 0.13 & 80.1 & 0.18 & 98.2 \\
\hline \multirow{3}{*}{3.} & \multirow{3}{*}{$\begin{array}{l}\text { Synechococcus } \\
\text { elongatus }\end{array}$} & 3 & 0.72 & 88.2 & 0.42 & 96.7 \\
\hline & & 6 & 0.08 & 97.6 & 0.12 & 99.0 \\
\hline & & 9 & 0.26 & 94.5 & 0.29 & 98.0 \\
\hline \multirow{3}{*}{4.} & \multirow{3}{*}{ Spirulina major } & 3 & 0.28 & 98.2 & 0.73 & 93.6 \\
\hline & & 6 & 0.09 & 97.4 & 0.46 & 96.0 \\
\hline & & 9 & 2.90 & 78.6 & 1.67 & 84.0 \\
\hline \multirow{3}{*}{5.} & \multirow{3}{*}{ Lyngbya trunicicola } & 3 & 0.46 & 92.0 & 0.04 & 99.6 \\
\hline & & 6 & 0.02 & 99.6 & 0.07 & 99.3 \\
\hline & & 9 & 1.56 & 70.2 & 0.18 & 98.8 \\
\hline
\end{tabular}

* Recovery 90\%, Mean standard error

Table.3 Physico-chemical analysis of industrial effluents collected from Karur

\begin{tabular}{|l|c|c|c|}
\hline \multicolumn{1}{|c|}{ Industrial effluent } & Unit & Textile Dye Industry & Paper Industry \\
\hline Colour & & Pale Blue & Colourless \\
\hline Temperature & ${ }^{\circ} \mathrm{C}$ & 32 & 33 \\
\hline $\mathrm{pH}$ & & 6.8 & 7.1 \\
\hline BOD & $\mathrm{mg} / \mathrm{l}$ & 260 & 289 \\
\hline COD & $\mathrm{mg} / \mathrm{l}$ & 640 & 686 \\
\hline DO & $\mathrm{mg} / \mathrm{l}$ & 2.4 & 2.6 \\
\hline Ammonia & $\mathrm{mg} / \mathrm{l}$ & 186 & 67 \\
\hline Nitrite & $\mathrm{mg} / \mathrm{l}$ & 76 & 75 \\
\hline Nitrate & $\mathrm{mg} / \mathrm{l}$ & 180 & 154 \\
\hline Organic Phosphate & $\mathrm{mg} / \mathrm{l}$ & 22 & 20 \\
\hline Inorganic Phosphate & $\mathrm{mg} / \mathrm{l}$ & 21 & 22 \\
\hline Calcium & $\mathrm{mg} / \mathrm{l}$ & 57 & 81 \\
\hline Chloride & $\mathrm{mg} / \mathrm{l}$ & 1268 & 1440 \\
\hline Magnesium & $\mathrm{mg} / \mathrm{l}$ & 46 & 70 \\
\hline
\end{tabular}


A perusal of literature reveals that Dubey et al., (2011), while assessing the use of cyanobacteria in bioremediation of industrial effluents also recorded a similar finding. In fact, they also noticed an enhanced degrading ability with an increase in residual concentration.

However, they recorded highest removal efficiency percentages during the fourth day. In the present study, it was uniformly noticed on the sixth day after which it decreased. Dubey et al., (2011) attributed this to accumulation of the species as well as appearance of mutants.

Results of the cyanobacterial combination studies on the effect of degradation at different concentrations are presented in Table-3. As evident from the table, at $5 \mathrm{ppm}$ residual concentration set-III containing a combination of Synecoccous and Spirulina recorded maximum degradation $(99.7 \%)$ on the third day, while Set-I having a combination of Anabaena and Spirulina recoded 100\% degradation on the sixth and ninth day. At $10 \mathrm{ppm}$ residual concentration, Set-III recorded highest degradation on third and sixth days, while Set-I recorded maximum degradation on the ninth day. A comparison between the individual and combination effect reveals that at $5 \mathrm{ppm}$ concentration, the cyanobacterial combination appeared to work more effectively than the individual combination.

However, a closer perusal of $10 \mathrm{ppm}$ concentration reveals that the individual species recorded higher degradation than the cyanobacterial combination. Hence, further studies need to be done to understand this phenomenon.

\section{References}

APHA (1998). Standard Methods for the Examination of Water and Wastewater. $18^{\text {th }}$ edition. American Public Health Association, Washington, DC, pp.4560.

Boomiathan, M. (2005). Bioremediation studies on dairy effluent using cyanobacteria. Ph.D. Thesis. Bharathidasan University. Tiruchirapalli. Tamil Nadu. India.

Cairns Jr. J. and Dickson, K. L. (1971). A simple method for the biological assessment of the effects of waste discharge on aquatic bottom dwelling organisms. $J$. Water Pollut. Control Fed. 43: 722-725.

Dubey, S. K., Dubey, J., Mehra, S., Tiwari, P. and Bishwas, A. J. (2011). Potential use of cyanobacteria species in bioremediation of industrial effluents. African Journal of Biotechnology, 10: 1125-1132.

Dubey, S. K., Dubey, J., Viswas, A. J. andTiwali, P. (2011) Studies on cyanobacterial biodiversity in paper mill and pharmaceutical industrial effluents. Br.Biotechnol. J., 1:61-67.

Kuritz, T., Bocanera, L. V. and Rivera, N. S. (1997). Dechlorination of lindane by the cyanobacterium Anabaena sp. strain PCC7120 depends on the function of the nir operon. J. Bacteriol. 179: 33683370 .

Lem, N. W., Glck, B. R. (1985). Biotechnological uses of cyanobacteria. Biotechnol. Adv., 3: 195-208.

Semyalo, R. P. (2009). The effects of cyanobacteria on the growth, survival, and behaviour of a tropical fish (Nile tilapia) and zooplankton (Daphnia lumholtzi). Ph.D. Thesis, University of Bergen, Norway.

\footnotetext{
How to cite this article:

Sagunthala S. and Sivakami R. 2017. Bioremediation of Industrial Effluents Using Fresh Water Cyanobacterial Species. Int.J.Curr.Res.Aca.Rev. 5(11), 44-47. doi: https://doi.org/10.20546/ijcrar.2017.511.008
}

Species. Int.J.Curr.Res.Aca.Rev. 5(11), 44-47. doi: hetps://doi.org/10.20546/ijcrar.2017.511.008 